\title{
Comedy of Entanglement: The Karrabing Film Collective
}

May Adadol Ingawanij

How to tell stories of relations and existence? This is a key question being posed across wideranging fields of practice to retune our imaginaries of ecological entanglement and possibilities of life in the Anthropocene. What processes of making, what expressive and combinatory forms, create affects and concepts that make tangible the connection between colonisation and environmental catastrophe, that embody imaginative futures and imaginaries of life for all? The novelist Amitav Ghosh speculates that the modern novel form itself, with its reality effects grounded in the investment in statistical probability and in the everyday of bourgeois ideology, is ill-suited to the contemporary urgency of narrating climate catastrophe. ${ }^{1}$ In his recent study of artistic practices and environmental engagement, the art historian T.J. Demos surveys speculative uses of film documentary, installation and artistic research to create different ways of perceiving the violence of state and corporate extraction and grasping moments of resistance and possibility. ${ }^{2}$ The multi-authored book Arts of Living on a Damaged Planet proposes the figures of the ghost and the monster, and the cultivation of skills of foraging and gathering rather than conquest, as components of ways of living and creating symbiotic stories within landscapes haunted by histories of human destruction and past intimations of different possible futures. ${ }^{3}$

My article approaches the short films of the Karrabing Film Collective as examples of audio-visual form and film-making praxis that use the comedic as a generative element. Humour strikingly shapes Karrabing's tactics of showing stories of ongoing and indeterminate existence in a damaged landscape of multiply intertwined and conflicted ecologies. In its self-description, Karrabing is a 'grassroots cooperative of friends and family members... whose lives interconnect all along the coastal waters immediately west of Darwin' in Australia's Northern Territory, and across the Anson Bay 'stretching outward into a global transnational network of curators, artists and filmmakers' ${ }^{4}$ To date, Karrabing has made a handful of short films whose stories and formal experimentations draw directly on the daily realities of $\amalg$ ndigenous existence in Australia. In the past decade Karrabing members have been evicted from their homes and have had personal relations badly affected by state policies that have served to obstruct Indigenous claims to recognition of ownership of land. Experiences within and immediate to this intergenerational and dispersed group ground its filmic analysis of 'contemporary settler colonialism', and the purpose of its filmmaking is to use the process, event and expressive capacities of film practice to keep moving within the corrosive and confined spaces of existence of Indigenous subjects in Australia - to make living a lively matter and to spot the potential to keep changing within the slow violence of settler late liberalism in order to 
'challenge its grip'. ${ }^{5}$ Over the past five years or so Karrabing's short films have circulated widely within the transnational circuits of contemporary art, film festivals and academic contexts. Englishlanguage publications by members of the group, and interviews with them, accompany Karrabing's pragmatics of mobilising visibility within transnational arts circuits, mediated by high profile members - mainly Columbia University professor Elizabeth Povinelli. ${ }^{6}$ References to the role of comedy and humour recur in these publications, most often in order to characterise the process and experience of film-making of the group as one of play and laughter, of spending and killing time, immersed in generating stories and filming them together. ${ }^{7}$

Rather than cover the same ground, I am interested in exploring humour in Karrabing's short films in terms of its strategy of enunciation and framing - as well as contextualising these works in relation to other moving-image practices whose formal strategies may be seen as adjacent to one another. Why take note of these formal aspects of Karrabing's film-making? Beyond the important if somewhat predictable point that humour remains an effective tool in countering clichéd portrayals of Indigenous existence as one of victimhood, conventionally drawn to the emotional tunes of the tragic, the solemn or the melancholic, paying attention to comedic tactics in Karrabing's short films opens up avenues for juxtaposing and exploring resonances between the collective's audio-visual praxis and those examples elsewhere that would not otherwise be brought into proximity with each other. My life circumstances and research activities do not enable me to make meaningful comments about the significance of Karrabing's films in the context of Australia's politics of culture, land and Indigenous subjectivity; rather, my take on its praxis is shaped partly by my continuing leftist attachment to the thoughts, styles, ambivalences and afterlives of those films and written works of Third Cinema. ${ }^{8}$ Karrabing's films capture my attention because they use humour and explore group dynamics, yet in different ways than do some of the canonical works of Third Cinema. Their experiment with unruly framing, creating disorientation through superimposition and shifting scales and directions of movement of objects and body parts in the frame, also resonate in rather unexpected ways with some works by contemporary artists in authoritarian regimes in Southeast Asia. Somewhat more randomly, the female elders in the films remind me of a fleeting figure of possibility among the extinguished and soon to be forgotten Red Shirts in Thai politics. That figure is manut paa, which literally translates as 'the auntie human type' - a figure that conjures the sturdy, mouthy, bumbag-slinging, stall-trading female of a certain age who no longer gave a shit and who every now and then made disruptive noises and minor obstructions at the edges of protest situations.

\section{Caricature of Circumstance}

Deleted: intellectual

Deleted: indigenous 
In When the Dogs Talked (2014), a visit by housing officials to the bungalow of a character, Gigi Lewis, based on a Karrabing member, triggers a reluctant journey. Young and old members of the extended family are surfing on whatever couch or floor surfaces they can fit in Gigi's small place. The officials have come to check up on reports of overcrowding; to buy some time, Gigi's sister goes to the door to tell them that her sister is not home. The officials demand that Gigi reports to them today, under threat of eviction, which leads the aunties to chivvy the group to get gas and phone credit so they can drive out into the country looking for her. A wayward, fractious search party eventually gets going. No one wants to be the first to offer to use their welfare card to fill the beaten-up truck. The vehicle breaks down on the red dirt road. A few of the men want to make a stop and go hunting instead. Family members they come across give contradictory information about where Gigi has gone and do not seem bothered by the situation. In any case, who can say for sure what the better outcome is, between hanging on in the cramped bungalow or losing the house and living an itinerant existence in tents in the country? More deliberations occur in Wutharr,

Saltwater Dreams (2016), which entertains multiple possible causes for a boat's breakdown: Rex says the wiring just needs changing; Trever's story is that it is the ancestors' punishment; and Linda says the Christian church is testing her faith. It could equally have something to do with the state. An official walks up to the low fence demarcating the scuzzy yard of the house where a group of older Karrabing characters are passing time; the women are sitting on the wooden bench by the tree and the men are gathered to the other side under the porch. The official hands Linda Yarrowin, the registered owner of the boat, a thick form that she must fill in for not meeting the safety measures. required to light a flare, She goes through each of the sections one by one. By the time the official is done reading out section five, 'settling [from welfare] payment', Linda's response is a sardonic mutter: 'far out'. She takes the form and passes it to another female to keep on reading. The question, peppered with legalese in Latin, demands a yes or no answer. The elder calls out across the yard to the men: 'What's the answer?' 'Yes', 'no', is the casually disorderly reply. Whatever answer goes down on paper ${ }_{2}$ there will likely be a fine to add to the existing toll that the accused already can't afford to pay.

Acts of unruly wandering, group undertakings and journeys that go awry recur across Karrabing's short films. The Indigenous characters' digressive journeys are often triggered by or made illicit by Kafkaesque state administration. In The Jealous One (2017), Rex Barramundi needs to cross the country to get to the spot on the beach where a funeral ritual will take place. He passes a sign prohibiting entry into Aboriginal territory without written permit and thus becomes a trespasser in his own country, pursued by an official. In the ensuing movement, commotion, digressions and detours, these journeys and their wanderers slide and spiral in overlapping time-space dimensions
Deleted: female elder

Deleted:
Commented [MOU1]: For clarity:
...fill in for not meeting the safety measures required to light
a flare.
or
...fill in in case someone on board who doesn't meet the
safety requirements lights a flare.
Deleted: as a consequence of somebody lighting the flare of a
boat that does not meet safety requirements...
Deleted: elder

Deleted: indigenous 
and indeterminate states. Such spiralling structures The Mermaids, or Aiden in Wonderland (2018), a speculative story set in the near future when white people must protect themselves by remaining indoors - only Aboriginal people can survive outdoor contact with contaminated land, water and creatures. The authority banishes the young \ndigenous man Aiden, who had been captured as a child and turned into a test specimen, to the outside where he meets two male family members. The older men initiate his wandering across his contaminated homeland and tell ancestral dreaming stories that contradict each other's, yet seem connected. Stories of creation become stories of ancestral rivalry and shifting alliance, where entanglements of dreamtime spawn variant speculative scenarios of surviving or surpassing the destruction of the whites. The trope of wandering, as Povinelli and others have observed, becomes Karrabing's method of representing landscape and embodying land, signalling affects and imaginaries of belonging and entanglement that differ from the settler colonial logic of land ownership and totemic recognition of Aboriginal land claims. ${ }^{9}$

The way these journeys unfold might be described as a kind of situational caricature. While the notion of caricature usually applies to those comedic modes that send up social types through exaggerated, parodic or grotesque portrayals of their bodies, I am thinking here of the translated English-language title of a collection of short stories by Indonesian writer Pramoedya Ananta Toer, Tales from Djakarta: Caricatures of Circumstances and their Human Beings. ${ }^{10}$ In his introduction to the stories, Benedict Anderson notes an inversion. The caricaturist here "works from his or her experience of life ... [and] ... announces her presence exactly as a teller of tales' ${ }_{2}^{11}$ Yet at the same time what is being exaggerated are the circumstances, in this case of the newly independent Indonesia, which created absurd situations for its human beings. The storyteller directs his or her satirical barb, drawn from life experiences, at the circumstances rather than their social types. Moments in Karrabing's films capture a parallel dynamic. In the scene in Wutharr where Linda hands the far-out form to another female, the camera catches a glimpse of an irrepressible laugh coming from one of the other women; another delivers a line of dialogue in a voice cracking with laughter. These moments charmingly heighten caricature's capacity for cutting to the quick, when the performers are simultaneously acting in character and laughing from experience at the fictional. circumstance, highlighting the routinised absurdity of state administrative delegitimisation of Indigenous existence.

\section{Discordant Relations}

Another distinctive way that comedy functions in the Karrabing's short films can be observed in comparison with the carnivalesque, an established trope in the films and theories of Third Cinema. Carnival creates ritualistic intervals of suspension of the rules of domination of the colonisers and 
the authorities. The carnivalesque creates utopian imaginaries of relations characterised by sensuous contact, carnality, conviviality and suspension of hierarchy. ${ }^{12}$ In its utopian duration the bodies of the oppressed intermingle and intertwine in collective waves, rhythms and energy. ${ }^{13}$ Time's texture and speculative power in Karrabing's films does not take on the form of the suspension of norms and institutions of domination. Instead, time figures through patterns of framing as riotous superimpositions and rescaling of object parts and body fragments within the frame. There is no outside of the everyday time of settler late liberal violence, yet that time of routinised administrative denial of life beyond the bare survival of Indigenous subjects intersects with and rubs against multiple other temporal scales, the deep time of partially connected and at times rivalling versions of ancestral dreaming with the deep time of geological change and the accelerated time of capitalist extraction. And instead of the carnivalesque's investment in and utopian images of energetically intertwined, libidinous collective bodies, the group in Karrabing's films is a fractious yet somehow inexhaustible entity.

The group in this context consists of generations of humans, and humans with relations to a multiplicity of ancestors with situated presence in the environment and embodied as animal forms. The portrait of intergenerational and kinship relations in Karrabing's films is one of discord easily and at times frivolously triggered. In Windjarrameru, The Stealing $C^{*} n t \$(2015)$, a group of young men bpen the cans of beer they stumble upon in the bush. They spot two male relatives painting a sign on the rock below and, with a mix of playfulness and aggression, chuck the empty cans at them. The argument between the old and young men spins out into multiple strands of claims, conflicts and subterfuge. Police officers turn up; so too does the sister of the rock painter, who as it turns out is freelancing for miners digging illegally in the area. Her grandchildren are among the young men hiding among the trees from the police. Brother and sister get into a noisy argument, and while the police are trying to calm this conflict another grandmother tries to free one of the young men already arrested who she had sent to spy on the miners. Night Time Go (2017) departs from other Karrabing films in incorporating archival actuality footage with fictional scenes sometimes presented in black and white and set in the past, to tell a speculative story of Karrabing ancestors as 'freedom fighters' who, with wooden sticks and bush survival skills, escape from an internment camp after the Second World War and force the retreat of the Australian army from their country. In the story, life in the camp is riven with conflicts. The inmates fight and accuse each other of stealing drinks and molesting their women. Gauging that their life in the camp is likely to be one of physical harm, death threats, petty rivalry and mutual suspicion, the Karrabing ancestor characters escape in small groups. These miraculously effective 'freedom fighters' wander and disappear in small clusters, uninterested in grand gestures of Indigenous sovereignty and bearing no 
evident symbol of collective solidarity, unaided by purposefully connected maps, underground networks or tunnel systems associated with the model of guerrilla resistance.

The camera held by someone who is familiar to the person being turned into an image can license a different degree of proximity and intimacy, and with results that may transgress the ethics of display or at least the etiquette of the publicly displayable. Martha Atienza's video Anito (2012), which records the carnivalesque duration of the annual Christian-animist Ati-Atihan procession on her home island of Bantayan in the Philippines, plays on its ambiguous status as, simultaneously, a neighbourhood movie and an artist's moving-image work. The woman behind the camera is in the thick of the procession and her body in synch with its wild rhythm. Her lens gets very close to the visibly drunk children staggering as they swig from liquor bottles. What is the difference between playing this footage in the neighbourhood the evening after the procession ends and projecting it elsewhere on the circuits of contemporary art and film? Anito speculatively superimposes neighbourhood and dispersed sites of projection, enacting an ambiguous elision in its trajectories of display. The video's indeterminate directions of address are simultaneously internal, addressed to fellow islanders in the neighbourhood who would recognise the kids and the context of festivity, and also external, available to strangers on art world circuits who may or may not reach beyond reading such images via the cliche of Philippine exotica. Atienza's work parallels in this sense the multidirectional expressive trajectories of Karrabing's films, which are simultaneously internally addressed as artefacts from an Indigenous group's praxis of play, and externally addressed as mobile works presented on transnational art and educational circuits.

\section{Unruly $\underline{\text { Superimpositions }}$}

The earlier Karrabing films, When the Dogs Talked and Windjarrameru, were shot on digital cameras by professional cinematographers accustomed to the pace and method of an industryfocussed production schedule. From Wutharr onwards the group shifted to shooting with iPhone cameras, with some of its members doing the cinematography, and adopting a different schedule, seemingly closer to the casual pace of home movies. ${ }^{14}$ Shifting to the phone camera apparatus has expanded the scope for portraying unruly group relations and entangled habituation. With these later films, the sense of subversiveness and disorientating energy are less derived from bodily performance than from enframing. The more recent films use extreme close-ups to a much greater degree, creating decentred images where body fragments take up a margin of the frame filled with earth, mud, water, sky, or all of these superimposed at once in saturated ochre or blue and pink palettes. A part of a foot occupies the lower left corner of the frame in an extremely low shot, with the camera at virtually ground level, such that the dry earth and trampled weeds fill the frame

Commented [MOU3]: Unfamiliar with idiom

Deleted: ready to hand lens

Deleted: indigenous 
extending into depth of field. A medium shot presents only the torso of a body moving towards the cameraperson, the head itself cut off the top frame line. A white 'hand of state' as the end credit of The Jealous One puts it, taps a keyboard. A dark hand marks incisions in the mudflats with a stick.

\section{Karrabing's experimentation with what may be termed unruly framing and superimposition}

resonates interestingly with a number of contemporary works of the south exploring parallel themes of political ecologies, intersubjective relations and environmental entanglements. Compared with the approach to representing human bodies in examples from the canon of Third Cinema,

Karrabing's camera phone enframing situates relations among bodies, and between bodies and matter, as embodying partial and fragmented connections - this is characterised by fluctuations and multidirectional ooziness and tensility of contact surface. In comparison, historical examples such as the dialectical film praxis of Ousmane Sembene's Ceddo (1977) shifts between long-distance shots visualising tableaux of bodies in circular groups and lines, and rapid zooms into close-ups of particular faces. As James Penney points out, such vacillation signals the dialectical relationship and movement between the circumstances and scope for agency and action of contending social groups and the perspectives and desires of individuals in them. ${ }^{15}$ In this earlier example, human bodies are figured as agents that make history under circumstances not of their choosing, and they do so with feet on stable ground and bodies in solid landscape.

In Karrabing's recent films, notably Mermaids and Wutharr, rather than figuring intersubjective relations as the dialectics of long-shot tableaux and zooms, the compact phone camera aesthetics frames Indigenous human entanglement in multiple ecologies and situated relations via unruly superimpositions of images, in aggregate layering a part of this face with a part of this human or the body of a fish, a bird, a mud_crab, a fly. Often, the framing superimposes fragments of a human, animal or mythological body on land with images of the mass and motility of water, mud or swamp. The elements intermingle through unruly superimposition in the frame, such that earth, water and fire, or salt and fresh water, do not so much meet at a certain threshold but pile and stack on top of each other, undermining the impression of gravitational pull and territorial volume and solidity. In film history, the technique of superimposition has typically been used to portray an individual's dream, fantasy or altered psychological states, or it has been used to create effects of the supernatural and the uncanny. And some early film practitioner-theorists approached film's capacity for superimposition as indication of the potential of cinematic consciousness and thinking independent of and beyond the capacity of the human brain. ${ }^{16}$ In the case of Karrabing's films, superimposition does something different. It figures multiplicity of times and versions of existence, and interconnection of ecologies, as the elemental medium of the characters' present-day existence. 
Superimposing extreme close-up images of the sparrow hawk and sea monster and a fragment of a human face situates the presentness of ancestral presence and people's ongoing relations with rivalrous but connected ancestral stories. Superimposition's transformation of landscape, sites and matter into gravitationally suspended layers is also a kind of dialectical figure. It ambiguously figures the potential for radically altered existence recalibrating human agency within ecologically multiple and entangled time-space. At the same time the enframing of de-solidified ground and unearthly movement of liquid alludes to the contamination of the environment as the now ubiquitous circumstance of existence.

Lastly, we might also note a striking affinity between the disorientating superimpositions in Karrabing's recent films and a number of artists' moving_image works of the south. Eduardo Williams' short film, Could See a Puma (2011), follows the wandering of a group of teenage boys from rooftop verandas to a flatland strewn with abandoned and half-demolished concrete buildings, onto the edges of a swamp and into a forest. Over the duration of the film, the boys walk, scramble and tumble in this eerie landscape of multidirectionally elastic time-space whose hues shift between mauve and a pinkish glow, dusk and nocturnal shadows. The film gradually renders the boys' languorous wandering in a manner transgressing the cinematic norm of showing humans walking laterally across the frame, a routine sight of human bodies traversing solid, inert space in gravitationally credible directions. The penultimate shot in Could See a Puma creates a vertiginous sensation when one of the boys exits the screen via a casual subterranean step, seemingly dipping through solid dark ground, and beyond the bottom frame line. A similarly incredible direction of movement down the bottom frame line also occurs in the works of Khvay Samnang and Taiki Sakpisit. Samnang's two-channel video installation, Preah Kunlong (2017), features a body with a headdress shaped from twigs and vines into forest creatures such as a peacock, an elephant or a crocodile, moving in an animistic dance in the Chong ancestral forest in Cambodia currently threatened with a hydro-electric megaproject. At times the use of disorientating extreme close-ups show a fragment of the human-animal's head in the bottom area of the frame. The flow of dance movement makes the head disappear offscreen, down past the bottom frame line; in a similar manner, Taiki's archival assemblage, Time of the Last Persecution (2013), recuts and slows down fragments of early 1980s Thai mythological films, intensifying the sense of a cosmos unmoored with psychedelic shots of swaying bodies sliding offscreen in downward slo-mo stroboscopic pulse. Less evidently excessive yet no less unruly in its conceptual approach to enframing are the exaggeratedly symmetric patterns of elegant camera movement linking Charles Lim Yi Yong's short film All the Lines Flow Out (2011) with his SEA STATE 6 (2016). In the former, Lim repurposes a slow, aquatic version of early cinema's phantom ride shot to figure the movement of 
water along the Singapore River out to the surrounding sea, the vast volume of water whose agency, liquidness and motility the official imaginary of Singapore's capitalist expansion tries to leave behind. In SEA STATE 6 the camera glides vertically down a tunnel system, moving smoothly yet strangely to the mellow rhythm of a retro pop tune down a massive underground tunnel system below an artificial island created from land reclamation in Singapore, developed for storing liquid hydrocarbons.

The formal expression and enunciation of humour in Karrabing's films corresponds with all of these techniques: centred around images, durations and processes; celebrating the unruliness and liveliness of beings across temporal and environmental scales. Their films are grounded in what we might call post-carnivalesque repertoires and potentials of ecological,relations, and on creating forms with human and nonhuman bodily modes of performance. As such, they are part of a contemporary ensemble taking reflexive approaches to the possibilities of cinematic movement and framing to explore human conducts - whether gigantic endeavours of mastery or microscopic wanderings - in entanglement with treacherous, indeterminate and politically shaped ecologies, and within tumultuous cosmologies unmaking humans at the limit of their power and capacity.

${ }^{1}$ Amitav Ghosh, The Great Derangement: Climate Change and the Unthinkable, Chicago: University of Chicago Press, 2016, pp.15-24.

2 T. J. Demos, Decolonizing Nature: Contemporary Art and the Politics of Ecology, Berlin: Sternberg Press, 2016, pp.167-98.

${ }_{3}$ Anna Lowenhaupt Tsing, Heather Anne Swanson, Elaine Gan and Nils Bubandt (ed.), Arts of Living on a Damaged Planet, Minneapolis: University of Minnesota Press, 2017, pp.G1-G14.

${ }^{4}$ Tess Lea and Elizabeth A. Povinelli, 'Karrabing: An Essay in Keywords', Visual Anthropology Review, vol.34, no.1, 2018 , p.37.

${ }^{5}$ Ibid.; see also E.A. Povinelli, Geontologies: A Requiem to Late Liberalism, Durham, NC: Duke University Press, 2016.

${ }^{6}$ For instance, 'Karrabing Film Collective: Wutharr: Saltwater Dreams, Introduced by Vivian Ziherl', Vdrome, available at http://www.vdrome.org/karrabing-film-collective-wutharr-saltwater-dreams; 'Episode \#18 Elizabeth Povinelli and Karrabing Film Collective', Conversations in Anthropology@Deakin [podcast], January 2019, available at https://soundcloud.com/anthro-deakin/ep18-povinelli; Spencer Lai, 'Growing up Karrabing: a conversation with Gavin Bianamu, Sheree Bianamu, Natasha Lewis Bigfoot, Ethan Jorrock and Elizabeth Povinelli', un Magazine, vol.11, no.2, 2017, available at http://unprojects.org.au/magazine/issues/issue-11-2/growing-up-karrabing/ (all links last accessed on 10 June 2019).

${ }^{7}$ A conversation with a number of Karrabing members, which highlights the collective's valuing of the ludic qualities of their praxis, appears in a recent issue of un Magazine devoted to humour in art. See ibid.

${ }^{8}$ Key books on Third Cinema include Jim Pines and Paul Willemen (ed.), Questions of Third Cinema, London: BFI

Publishing, 1990; Michael T. Martin (ed.), New Latin American Cinema Volume 1: Theory, Practices, and

Transcontinental Articulations, Detroit: Wayne State University Press, 1997; Ella Shohat and Robert Stam, Unthinking

Eurocentrism: Multiculturalism and the Media, Abingdon: Routledge, 2014.

${ }^{9}$ T. Lea and E.A. Povinelli, Geontologies, op cit., p.39; Gabrielle O’Brien, 'Keeping Country Alive: Dreaming,

Decolonisation and the Karrabing Film Collective', Metro Magazine, no.199, 2019, pp.108-13.

${ }^{10}$ See Pramoedya Ananta Toer, Tales from Djakarta: Caricatures of Circumstances and their Human Beings, Ithaca,

NY: Cornell University Press, 1999.

${ }^{11}$ Benedict R. O’G. Anderson, 'Introduction', in ibid., p.14.

Deleted: the carnal performativity of human bodies

\section{Deleted: the}

Deleted:

Deleted: transindividual

Deleted: exhibitionistic 
12 To borrow from Robert Stam's useful summary; see Robert Stam, Keywords in Subversive Film/Media Aesthetics, Hoboken, NJ: Wiley-Blackwell, 2015, pp.79-86.

See ibid., pp.68-100.

${ }^{14}$ See 'Growing up Karrabing', op . cit.

${ }^{15}$ See James Penney, 'Zooming Out: Sembene's Ceddo and Third Cinema Aesthetics,' Canadian Journal of Film Studies, vol.24, no.1, March 2015, pp.2-24.

${ }^{16}$ See Daniel Morgan, 'The Afterlife of Superimposition', in Dudley Andrew (ed.), Opening Bazin: Postwar Film Theory and its Afterlife, Oxford: Oxford University Press, 2011, pp.127-41. 